\title{
Hands hygiene and the use of gloves by nursing team in hemodialysis service
}

\author{
Higiene das mãos e uso de luvas pela enfermagem em hemodiálise \\ Higiene de las manos y el uso de guantes por la enfermería en hemodiálises
}

\section{Darlyani Mariano da Silva', Bianca Miranda Marques', Nathalia Malaman Galhardi', Fabiana de Souza Orlandi', Rosely Moralez de Figueiredo'}

' Universidade Federal de São Carlos. São Carlos, São Paulo, Brazil.

How to cite this article:

Silva DM, Marques BM, Galhardi NM, Orlandi FS, Figueiredo RM. Hands hygiene and the use of gloves by nursing team in hemodialysis service. Rev Bras Enferm [Internet]. 2018;71(4):1963-9. DOI: http://dx.doi.org/10.1590/0034-7167-2017-0476

\section{ABSTRACT}

Objective: to analyze the adhesion of the nursing team to the practice of hands hygiene $(\mathrm{HH})$ and the use of latex gloves in a hemodialysis service. Method: this is a descriptive-exploratory study with a quantitative approach, performed between August and October 2016 in a hemodialysis service in the countryside of São Paulo State, Brazil, where the nursing team adhered to $\mathrm{HH}$ and the use of gloves. All ethical aspects have been contemplated. Results: there were 1090 opportunities for $\mathrm{HH}$, with the adhesion rate being only $16.6 \%$. Regarding the use of gloves, of the 510 opportunities observed, there was correct use in $45 \%$, reuse in $25 \%$ and absence of latex gloves in $29 \%$ of the time. Conclusion: the rate of $\mathrm{HH}$ and adherence to gloves is far from ideal, contributing to the increased risk of infection for both the user and the professional.

Descriptors: Hands Hygiene; Kidney Dialysis; Nursing Team; Hospital Infection; Universal Precautions.

\section{RESUMO}

Objetivo: analisar a adesão da equipe de enfermagem à prática de higienização das mãos (HM) e ao uso de luvas em um serviço de hemodiálise. Método: estudo descritivo-exploratório de abordagem quantitativa, realizado entre agosto e outubro de 2016 em um serviço de hemodiálise do interior do Estado de São Paulo, Brasil, onde foi observada a adesão da equipe de enfermagem à $\mathrm{HM}$ e ao uso de luvas. Todos os aspectos éticos foram contemplados. Resultados: observou-se 1090 oportunidades de HM, sendo a taxa de adesão de apenas 16,6\%. Quanto ao uso de luvas, das 510 oportunidades observadas, houve utilização correta em 45\%, a reutilização em $25 \%$ e ausência do uso de luvas em $29 \%$ das vezes. Conclusão: a taxa de HM e a adesão ao uso de luvas estão muito aquém do ideal, contribuindo para o aumento do risco de infecção, tanto para o usuário como para o profissional.

Descritores: Higiene das Mãos; Diálise Renal; Equipe de Enfermagem; Infecção Hospitalar; Precauções Universais.

\section{RESUMEN}

Objetivo: analizar la adhesión del equipo de enfermería a la práctica de higienización de las manos (HM) y al uso de guantes en un servicio de hemodiálisis. Método: el estudio descriptivo-exploratorio y cuantitativo, realizado entre agosto y octubre de 2016 en un servicio de hemodiálisis del interior del estado de São Paulo, Brasil, donde se observó la adhesión del equipo de enfermería a la HM y al uso de guantes. Todos los aspectos éticos fueron contemplados. Resultados: se observó 1090 oportunidades de HM, siendo la tasa de adhesión de apenas el 16,6\%. En cuanto al uso de guantes, de las 510 oportunidades observadas, hubo utilización correcta en un $45 \%$, la reutilización en un $25 \%$ y ausencia del uso de guantes en un $29 \%$. Conclusion: la tasa de HM y la adhesión al uso de guantes están muy por debajo del ideal, contribuyendo al aumento del riesgo de infección, tanto para el usuario y para el profesional.

Descriptores: Higiene de las Manos; Diálisis Renal; Equipo de Enfermería; Infección Hospitalaria; Precauciones Universales. 


\section{INTRODUCTION}

The Chronic Kidney Disease (CKD) is considered a public health problem, since its prevalence has increased year by year worldwide. This pathological process can lead to an evolution to End-Stage Kidney Disease (ESKD), requiring some type of Renal Replacement Therapy (RRT), such as hemodialysis, peritoneal dialysis and kidney transplantation ${ }^{(1)}$.

In Brazil, about 36 thousand patients started chronic dialysis in 2014 , and of these, $90.8 \%$ underwent hemodialysis ${ }^{(2)}$. An access is needed to perform hemodialysis. The access is where you receive hemodialysis. Using the access, blood is removed from your body, cleaned by the dialysis machine (called the dialyzer), and then returned to your body ${ }^{(3)}$.

Infection is the second cause of mortality among patients with ESKD, representing approximately $14 \%$ of deaths among them, preceded only by cardiovascular diseases ${ }^{(4-5)}$.

Nursing plays an extremely important role in the care of the patient with chronic kidney disease, focusing on the prevention of infections, promoting self-care, family and patient orientations, and promoting a comfortable environment ${ }^{(6)}$. In this sense, the nurse has an essential role in hemodialysis, acting directly in the planning and execution of these cares ${ }^{(7)}$.

Patients undergoing hemodialysis have a high risk for the contraction of Healthcare-Associated Infections (HCAI), as well as the acquisition of multi-drug-resistant microorganism ${ }^{(8)}$. The handling of devices, such as catheters, and colonization of the skin at the site during of its insertion, can be related as the main etiology of infections. Predisposing factors, such as: immunosuppression of patients being treated, inadequate diet, comorbidities, several patients simultaneously dialyzing in the same environment, handling of devices and the length of time the catheter stays for long periods ${ }^{(9)}$.

Hands hygiene $(\mathrm{HH})$ is one of the most important measures for the control of HCAI. The hands of healthcare professionals are the main route of transmission of exogenous infections mainly through invasive procedures ${ }^{(10)}$. Improving $\mathrm{HH}$ should be a priority for health authorities at all levels, in addition to the individual responsibility of each health professional|(11).

In Brazil, efforts are focused on infection control; where in Brazilian legislation through Resolution $n^{\circ}$ 50/2002 the minimum actions to be contracted are established with a view to reducing the incidence of $\mathrm{HCAl}$ and the physical standards and projects of care institutions of health ${ }^{(12)}$. The World Health Organization (WHO), through the World Alliance for Patient Safety, has also dedicated efforts in the preparation of guidelines and strategies for the implementation of measures aimed at adhering to the practice of hands hygiene ${ }^{(13)}$.

In hemodialysis services, the complexity of the actions and peculiarity of the patients with chronic kidney disease stands out. To perform hemodialysis requires specific procedures and, for practitioners it is required the use of health protection and safety measures, such as the adoption of standard precaution ${ }^{(14)}$. Failure to comply with patient protection standards and non-in-service training for professionals directly influence the risk of contracting $\mathrm{HCAl}^{(15)}$.

Studies on adherence to $\mathrm{HH}$ in health services have high rates of non-compliance, with reports of factors that hinder their action, such as haste and lack of time ${ }^{(16-18)}$. Considering the high risk of HCAl for the patient and healthcare professionals, since they undergo repeated invasive procedures, and professionals, with the frequent handling of blood, it is of utmost importance to guarantee the ideal requirements for $\mathrm{HH}$, including valuing the existence of a high frequency of opportunities for its realization ${ }^{(19)}$.

The adequate use of gloves, associated to the practice of $\mathrm{HH}$, is a determining factor for the protection of the professional during health care ${ }^{(19)}$. According to NR 32 (Regulatory Norm), which legislates for the purpose of establishing the basic guidelines for the implementation of measures to protect the health and safety of health workers, the use of gloves does not replace the $\mathrm{HH}$ process, which must occur at least before and after their $\mathrm{use}^{(20)}$. Reducing the risk of HCAl on hemodialysis reflects on the improvement of quality of services provided, as well as on the quality of life of the patient with chronic kidney disease.

Considering the high number of patients undergoing dialysis, the relevance of the nursing role and the importance of HCAI prevention in this setting is that it was proposed to carry out this study, in which the nursing team adhered to $\mathrm{HH}$ and the use of gloves.

\section{OBJECTIVE}

To analyze the adherence of the nursing team to the practice of hands hygiene and latex glove use in a hemodialysis in the countryside of São Paulo State.

\section{METHOD}

\section{Ethical aspects}

The resolution 466/12 was respected, the project was approved by the Research Ethics Committee (REC) with human beings from the Universidade Federal de São Carlos (Federal University of São Carlos) and all participants signed the Informed Consent.

\section{Design, place of study and study period}

This is a descriptive-exploratory study, with a quantitative approach, performed in the period from August to October 2016, in a hemodialysis unit in the interior of the state of São Paulo - Brazil. The unit provides care to patients who are contracted and predominantly from the Brazilian Unified Health System (SUS). During the study period, there were 180 patients undergoing treatment, with sessions occurring three times a week.

\section{Population, inclusion and exclusion criteria}

30 nursing professionals work in this service (four nurses, 23 nursing technicians and three nursing assistants). The work is organized in two teams in the morning shift and two in the afternoon shift, who work on alternate days. The observation was carried out equally between the different teams and shifts.

The inclusion criteria adopted were to be a member of the nursing team and to work in the cited sector during the period of data collection. Licensed professionals, professionals on vacation and professionals with work leave were excluded during data collection.

\section{Study protocol}

After a previous evaluation of the place, it was decided to perform the data collection through two observers, since the patients were distributed in two different rooms, and there was inclusion of the observation of the use of gloves, since the inadequate use of this 
one influenced directly at $\mathrm{HH}$ at different opportunities. Another aspect identified was that due to the simultaneity of the procedures and the need to guarantee the anonymity of the professional, it was decided to observe if they made the hands hygiene or not and if they used gloves, independent of the professional who performed it.

The road map for the data collection, elaborated from then on, contained the list of procedures to be observed (preparation in the capillary placement, puncture and connection of the Arteriovenous Fistula (AVF) hemodialysis, Foley Catheter (FC) dressing, disconnection of AVF access, disconnection of FC access, handling of extension with blood fluids, hemodialysis connection in FC, and the possibility of identifying the opportunities of $\mathrm{HH}$ "before" and "after" the accomplishment of the same. In order to evaluate the structure for $\mathrm{HH}$, the indicator of Infrastructure Assessment for Washing Hands was used ${ }^{(21)}$.

\section{Analysis of results and statistics}

The OpenEpi public domain program version 3.0 ${ }^{(22)}$ was used for the sample calculation, which indicated the need for a minimum observation of 384 procedures, that is, 768 opportunities, taking into account the moments "before" and "after" procedure. However, the perspective of the data collection by opportunities allowed a greater number of observations, reaching 1090 opportunities, which raised the confidence interval of the sample calculation to $99.9 \%$.

Adhesion rates were calculated from the relative frequencies of adherence to $\mathrm{HH}$ and the use of gloves for each procedure. The data were organized and stored in a database using the Microsoft Excell $2010^{\circledR}$ program and performed descriptive statistical analysis with the help of the Statistical Package for the Social Sciences (SPSS), version $22^{(23)}$.

\section{RESULTS}

$\mathrm{HH}$ was performed in only $182(16.6 \%)$ of the 1,090 identified opportunities. Table 1 shows the relative frequencies of $\mathrm{HH}$ adhesion in the opportunities "before" or "after" the procedures, in addition to the $\mathrm{HH}$ Adhesion Indicator for each type of procedure.
The most frequent and, consequently, the most observed procedures were those related to puncture/connection and disconnection of the AVF. AVF puncture and connection obtained a total of 372 $\mathrm{HH}$ opportunities, with the adhesion rate of $7.6 \%$ for "before" and $23.5 \%$ for "after" the procedure. Regarding the disconnection of AVF access in the 207 opportunities observed, the "before" and "after" adhesion rate was $7.6 \%$ and $33.9 \%$ respectively.

The general rate of adherence to $\mathrm{HH}$ "after" procedure of $27 \%$ was higher than the general " $\mathrm{HH}$ " adherence rate of $6.4 \%$ in all procedures observed (Table 1). Regarding the product used, the use of soap and water was the first choice in $162(89 \%)$ and alcoholic solution in 20 (12\%) of the opportunities used.

The $\mathrm{HH}$ technique performed by the professionals was also observed 176 times of the $182 \mathrm{HH}$ observed, noting that in only one time the professional followed all the steps recommended by the $\mathrm{WHO}^{(19)}$.

Regarding the physical structure, in each hemodialysis room contained a sink that complied without any irregularities, such as the use of cloth, lack of water, dirty dispenser or soap, broken faucet or dirt visible in the sink. The availability of alcoholic solution at the point of care was not identified, ie close to each hemodialysis machine.

Table 2 - Frequency distribution and characteristics of latex gloves used by nursing professionals in hemodialysis service, São Carlos city, São Paulo State, Brazil, 2017

\begin{tabular}{lcccc}
\hline & \multicolumn{4}{c}{ Use of Latex Gloves } \\
\cline { 2 - 5 } Observed Procedures & $\begin{array}{c}\text { Coreect } \\
\text { use }\end{array}$ & Reuse & Absence Total \\
\hline Preparing capillary placement & 20 & 59 & 41 & 120 \\
Puncture and connection of AVF hemodialysis & 120 & 32 & 31 & 183 \\
Disconnection of AVF access from hemodialysis & 34 & 17 & 34 & 85 \\
Disconnection of FC access from hemodialysis & 4 & 0 & 0 & 4 \\
Handling of extensions with blood fluids & 21 & 19 & 42 & 82 \\
Hemodialysis connection in FC & 34 & 2 & 0 & 36 \\
Total & 233 & 129 & 148 & 510 \\
\hline
\end{tabular}

Note: $A V F=$ Arteriovenous Fistula; $F C=$ Foley Catheter

Table 1 - Frequency distribution and rate of adhesion to the procedures of hands hygiene by nursing professionals in hemodialysis service, São Carlos city, São Paulo State, Brazil, 2017

\begin{tabular}{|c|c|c|c|c|c|c|c|c|}
\hline \multirow{2}{*}{ Observed procedures } & \multicolumn{2}{|c|}{$\begin{array}{l}\text { HH before the } \\
\text { procedure }\end{array}$} & \multirow{2}{*}{$\begin{array}{c}\text { Total of } \\
\text { Observations }\end{array}$} & \multirow{2}{*}{$\begin{array}{l}\text { Adherence } \\
\text { rate } \\
(\%)\end{array}$} & \multicolumn{2}{|c|}{$\begin{array}{l}\text { HH after the } \\
\text { procedure }\end{array}$} & \multirow{2}{*}{$\begin{array}{c}\text { Total of } \\
\text { Observations }\end{array}$} & \multirow{2}{*}{$\begin{array}{c}\text { Adherence } \\
\text { rate } \\
(\%)\end{array}$} \\
\hline & $\begin{array}{c}\text { Water } \\
\text { and soap }\end{array}$ & $\begin{array}{c}\text { Alcoholic } \\
\text { preparation }\end{array}$ & & & $\begin{array}{c}\text { Water } \\
\text { and soap }\end{array}$ & $\begin{array}{l}\text { Alcoholic } \\
\text { preparation }\end{array}$ & & \\
\hline Preparing capillary placement & 3 & 0 & 120 & 2.5 & 16 & 0 & 95 & 16.8 \\
\hline Puncture and connection of AVF hemodialysis & 12 & 2 & 185 & 7.6 & 40 & 4 & 187 & 23.5 \\
\hline Dressing the FC & 3 & 1 & 27 & 14.8 & 21 & 0 & 28 & 75.0 \\
\hline Disconnection of AVF access & 4 & 3 & 92 & 7.6 & 32 & 7 & 115 & 33.9 \\
\hline Disconnection of FC access & 1 & 0 & 7 & 14.3 & 1 & 2 & 7 & 42.9 \\
\hline Handling of extensions with blood fluids & 3 & 1 & 78 & 5.1 & 11 & 0 & 75 & 14.7 \\
\hline Hemodialysis connection in FC & 2 & 0 & 36 & 5.6 & 13 & 0 & 38 & 34.2 \\
\hline Total & 28 & 7 & 545 & 6.4 & 134 & 13 & 545 & 27.0 \\
\hline
\end{tabular}

Note: $A V F=$ Arteriovenous Fistula; FC = Foley Catheter; $\mathrm{HH}=$ Hands Hygiene. 
There were also 510 opportunities for the use of gloves, as described in Table 2. It was considered as "correct use" when at the beginning of the procedure the professional put on new procedure gloves. "Reuse" refers to the time when the practitioner uses the same glove in more than one patient. And "absence" means that the professional did not use procedure gloves, although there was indication. The incorrect use of gloves, reuse and absence of gloves, was superior to $54 \%$ of the observed opportunities.

\section{DISCUSSION}

In the present study, 1090 opportunities for $\mathrm{HH}$ were identified, and this was performed in only 182 (16.6\%) of them, resembling a multicenter study performed in dialysis units in Spain, where adherence to $\mathrm{HH}$ was only $13,8 \%$ before contact with the patient and $35.6 \%$ after $\operatorname{contact}^{(24)}$.

The fact that low adherence to $\mathrm{HH}$ is more pronounced at the time "before" contact with the patient has also been previously reported in the literature both for other health services in general ${ }^{(17,25-26)}$ and for the hemodialysis service ${ }^{(8)}$. These data suggest that the professional recognizes the importance of $\mathrm{HH}$ more for its own protection than for patient safety ${ }^{(27)}$.

Adherence to $\mathrm{HH}$ is considered a basic care in all health care, however, it gains an even larger dimension in hemodialysis units, considering the complexity of these units and the exposure of professionals to frequent contact with large quantities of organic fluids ${ }^{(28)}$. A study that evaluated 13 specific components of the HF Maintenance Indicator for Hemodialysis showed that nine of them obtained $100 \%$ compliance and $\mathrm{HH}$ presented one of the worst rates $(83.9 \%)$, showing the fragility in adherence to the practice ${ }^{(29)}$.

It is worth mentioning that in addition to the low adherence to $\mathrm{HH}(16.6 \%)$ found in the present study; only one observation was made following the $\mathrm{WHO}$ recommended steps (WHO, 2014). A similar result was found in a study conducted at a school hospital in Goiânia city, where no nursing professional performed the $\mathrm{HH}$ technique as recommended by the literature ${ }^{(30)}$.

The preference for the use of soap and water $162(89 \%)$ to the detriment of the alcohol preparation $20(12 \%)$, identified in this study, is corroborated in the literature ${ }^{(17,26,31)}$. In the study service, it was verified that there are two types of gloves available, with talc and without talc, factor that may have influenced in the preference for the use of water and soap in detriment of the alcoholic solution. The use of alcoholic preparation is recommended by the $\mathrm{WHO}$ as the main means of routine hand hygiene, being considered fast and effective for inactivation of a large number of microorganisms ${ }^{(19)}$. In Brazil, ANVISA's Resolution of the Collegiate Board (RDC), №. 42, September 2010, on the use of alcoholic preparation, guarantees the antimicrobial efficacy of the $70 \%$ alcohol preparation in any formulation, and can thus be used for $\mathrm{HH}^{(32)}$.

A study comparing the two $\mathrm{HH}$ techniques in peritoneal dialysis patients demonstrated that sanitation with alcohol preparation produced a greater reduction in the number of colony forming units when compared to a non-antimicrobial $\operatorname{soap}^{(33)}$.

Regarding the physical and material structure for hands hygiene, no irregularities were found in this study, contrary to other studies where deficiencies in the infrastructure, as well as the nonavailability of materials favored non-adherence to $\mathrm{HH}^{(34-35)}$. Thus, it is evident that the available infrastructure is important for $\mathrm{HH}$, but it does not guarantee the expected results. The institutions must carry out a set of actions that encourage this practice, facilitating the performance of $\mathrm{HH}^{(17,35)}$. Interventions such as the provision of alcoholic preparation, leadership involvement, informative leaflets and health education have been indicated as important strategies to improve $\mathrm{HH}$ adherence of health professionals ${ }^{(36-37)}$.

Regarding the use of gloves, the data obtained surprised both the high rate of reuse of gloves (25\%) and the absence of use $(29 \%)$ in the indicated situations. A study carried out at a hemodialysis clinic in Vietnam for the investigation of hepatitis $\mathrm{C}$ outbreak showed that adherence to the use of gloves was $100 \%$ for dressings, $100 \%$ during cleaning of the dialysis room, $93 \%$ for the handle of veins and arteries of patients, $86 \%$ for disconnection and $75 \%$ for material disposal. However, the authors also reported that the work process was organized for simultaneous care of several patients and the use of the same glove for the care of more than one patient was frequent ${ }^{(38)}$.

It is known that the indiscriminate or inadequate use of gloves may be associated with the transmission of pathogens and, in addition, the use of gloves does not replace $\mathrm{HH}$ and this should occur at least before and after the use of gloves ${ }^{(20,39)}$.

A study performed in a small general hospital in the state of São Paulo observed the use of the same glove in more than one patient, in the handling of different sites of the same patient and in the touch of surfaces outside the bed ${ }^{(40)}$. Another study carried out with nursing technicians found that from all lost opportunities of $\mathrm{HH}$ in 13 $(22.0 \%)$ of them, the professional was using procedure gloves, that is, it reinforces that the inappropriate use of gloves influences $\mathrm{HH}^{(31)}$.

Another worrying situation found in the present study was the absence of gloves in $29 \%$ of the opportunities observed. Procedure gloves are a protective barrier for health professionals when exposed to biological material, being one of the main personal protective equipment (PPE) for this professional group ${ }^{(41)}$. A review study carried out in Saudi Arabia highlights the importance of the use of gloves to perform hemodialysis, both for professional protection and for the prevention and control of $\mathrm{HCAl}^{(42)}$.

In the present study, $17 \%$ of the AVF punctures were performed without gloves. Studies with the nursing team about adherence to standard precautions show that it is common for procedures such as venipuncture to be performed without gloves, in total disagreement with current recommendations ${ }^{(43-45)}$.

Factors such as haste, excessive talc powder and unavailability of correct size are mentioned as a barrier to adhesion to gloves ${ }^{(40,45)}$. In the hemodialysis service, the poor quality of the AVF was pointed out by nursing professionals, as difficulties for the use of gloves during the handling of the $\operatorname{AVF}^{(38)}$. The authors continue to affirm that individualized patient care is necessary to minimize the risk of microorganism transmission, enhanced by concomitant contact with multiple patients, as identified in the present study ${ }^{(38)}$.

\section{Study limitations}

Due to the complexity and dynamics of the unit it was not possible to establish a proportional number of observations between the different procedures. In addition, it should be noted that the data obtained here refer to a single unit and, although in line with the current literature, they cannot be extrapolated. 
Contributions to the nursing, health or public policy sectors

It is understood that the findings of this investigation are extremely important, as they reveal the need for professionals and managers of hemodialysis services to rethink their work processes. Shared, nonpatient focused work can contribute to low $\mathrm{HH}$ compliance rates and adequate glove use. It is hoped that nurses can assume their role as care manager, thus reviewing their practices in order to guarantee the quality of care, patient safety and the health of the professional.

\section{CONCLUSION}

There was a low rate of adherence to $\mathrm{HH}$ by the nursing team, and the adhesion was even worse at the time "before" the procedures were performed and the use of soap and water was the first choice option, in detriment to the use of the alcohol solution.

Regarding the use of gloves, problems in adherence were identified both by the high rate of reuse and by the absence of the same in the indicated situations. It was also identified that the nursing actions occur concomitantly with more than one patient.

\section{FUNDING}

The project was funded by the Foundation for Research Support of the State of São Paulo (FAPESP) 2016-07118-5 process, through a scientific initiation scholarship.

\section{REFERENCES}

1. Brasil. Ministério da Saúde. Secretaria de Atenção à Saúde. Departamento de atenção especializada e temática. Diretrizes clínicas para o cuidado ao paciente com doença renal crônica no Sistema Único de Saúde. Brasília, DF: MS; 2014.

2. Sesso RC, Lopes AA, Thomé FS, Lugon JR, Santos DR. Brazilian Chronic Dialysis Survey 2013 - Trend analysis between 2011 and 2013. J Bras Nefrol[Internet]. 2014[cited 2017 Jun 26];36(4):476-81. Available from: http://www.scielo.br/pdf/jbn/v36n4/en_01012800-jbn-36-04-0476.pdf

3. Sousa MRG, Silva AEBC, Bezerra ALQ, Freitas JS, Miasso AI. Adverse events in hemodialysis: reports of nursing professionals. Rev Esc Enferm USP[Internet]. 2013[cited 2017 Jun 08];47(1):76-83. Available from: http://www.scielo.br/pdf/reeusp/v47n1/en_a10v47n1.pdf

4. Saran R, Robinson B, Abbott KC, Agodoa LYC, Albertus P, Ayanian J, et al. US Renal Data System 2016 Annual Data Report: epidemiology of kidney disease in the United States. Am J Kidney Dis[Internet]. 2017[cited 2017 Jun 08];69(3-Suppl-1):S1-S688. Available from: https://linkinghub.elsevier.com/retrieve/pii/S0272-6386(16)30703-X

5. Esmanhoto CG, Taminato M, Fram DS, Belasco AGS, Barbosa DA. Microorganisms isolated from patients on hemodialysis by central venous catheter and related clinical evolution. Acta Paul Enferm[Internet]. 2013[cited 2017 Jun 08];26(5):413-20. Available from: http://www.scielo.br/pdf/ape/v26n5/en_a03v26n5.pdf

6. Frazão CMFQ, Delgado MF, Araújo MGA, Silva FBBL, Sá JD, Lira ALBC. Nursing care for chronic renal patients on hemodialysis. Rev Rene[Internet]. 2014[cited 2012 Jun 09];15(4):701-9. Available from: http://www.revistarene.ufc.br/revista/index.php/revista/ article/viewFile/1592/pdf_1

7. Freitas RLS, Mendonça AEO. Cuidados de enfermagem ao paciente renal crônico em hemodiálise. Carpe Diem[Internet]. 2016[cited 2017 Jun 26];14(2):22-35. Available from: https://periodicos.unifacex.com.br/Revista/article/view/678/pdf

8. Scheithauer S, Eitner F, Mankartz J, Haefner H, Nowicki K, Floege J, et al. Improving hand hygiene compliance rates in the haemodialysis setting: more than just more hand rubs. Nephrol Dial Transplant[Internet]. 2012[cited 2017 Jun 07];27(2):766-70. Available from: http://dx.doi.org/10.1093/ndt/gfr365

9. Ferreira AC, Deprá MM, Pies OT, Sousa IC, Rocha LK, Saraiva Filho JC. Infecções em cateter de hemodiálise: aspectos microbiológicos e de resistência em uma unidade de referência de Belém. Rev Soc Bras Clin Med[Internet]. 2014[cited 2017 Jun 08];12(4):a4372. Available from: http://files.bvs.br/upload/S/1679-1010/2014/v12n4/a4372.pdf

10. Reisdorfer AS. Infecção em acesso temporário para hemodiálise: estudo em pacientes com insuficiência renal crônica[Dissertação]. Porto Alegre: Universidade Federal do Rio Grande do Sul; 2011.

11. Škodová M, Benítez AG, Redondo EM, Cortés JFM, Romano RJ, Ortiz AG. Hand hygiene technique quality evaluation in nursing and medicine students of two academic courses. Rev Latino-Am Enfermagem[Internet]. 2015[cited 2017 Jun 08];23(4):708-17. Available from: http://www.scielo.br/pdf/rlae/v23n4/0104-1169-rlae-23-04-00708.pdf

12. Brasil. Ministério da Saúde. Agência Nacional de Vigilância Sanitária. Resolução RDC no. 50, de 21 de fevereiro de 2002 . Dispõe sobre o regulamento técnico para planejamento, programação, elaboração e avaliação de projetos físicos de estabelecimentos assistenciais de saúde. Diário Oficial da União, 20 mar 2002.

13. Brasil. Agência Nacional de Vigilância Sanitária. Higienização das mãos em serviços de saúde. Brasília, DF: Anvisa; 2007.

14. Silva MKD, Zeitoune RCG. Riscos ocupacionais em um setor de hemodiálise na perspectiva dos trabalhadores da equipe de enfermagem. Esc Anna Nery Rev Enferm[Internet]. 2009[cited 2017 Jun 08];13(2):279-86. Available from: http://www.scielo.br/ pdf/ean/v13n2/v13n2a07.pdf

15. Santos SF, Viana RS, Alcoforado CLG, Campos CC, Matos SS, Ercole FF. Ações de enfermagem na prevenção de infecções relacionadas ao cateter venoso central: uma revisão integrativa. Rev SOBECC[Internet]. 2014[cited 2017 Jun 06];19(4):219-25. Available from: 
http://sobecc.org.br/arquivos/artigos/2015/pdfs/v19n4/SOBECC_v19n4_219-225.pdf

16. Jardim JM, Lacerda RA, Soares NJD, Nunes BK. Evaluation of practices for the prevention and control of bloodstream infections in a government hospital. Rev Esc Enferm USP[Internet]. 2013[cited 2017 Jun 08];47(1):38-45. Available from: http://www.scielo. br/pdf/reeusp/v47n1/en_a05v47n1.pdf

17. Santos TCR, Roseira CE, Morais THP, Figueiredo RM. Hand hygiene in hospital environments: use of conformity indicators. Rev Gaúcha Enferm[Internet]. 2014[cited 2017 Jun 08];35(1):70-7. Available from: http://www.scielo.br/pdf/rgenf/v35n1/1983-1447rgenf-35-01-00070.pdf

18. Mota ÉC, Barbosa DA, Silveira BRM, Rabelo TA, Silva NM, Silva PLN, et al. Higienização das mãos: uma avaliação da adesão e da prática dos profissionais de saúde no controle das infecções hospitalares. Rev Epidemiol Control Infect[Internet]. 2014[cited 2017 Jun 08];4(1):12-17. Available from: https://online.unisc.br/seer/index.php/epidemiologia/article/view/4052/3379

19. Organização Mundial da Saúde-OMS. SALVE VIDAS: Higienize suas Mãos. Higiene das Mãos na Assistência à Saúde Extra-hospitalar e Domiciliar e nas Instituições de Longa Permanência - Um Guia para a Implementação da Estratégia Multimodal da OMS para a Melhoria da Higiene das Mãos e da Abordagem "Meus 5 Momentos para a Higiene das Mãos"; tradução de OPAS - Brasília: Organização Pan-Americana da Saúde; Agência Nacional de Vigilância Sanitária; 2014. 73 p.

20. Brasil. Ministério do Trabalho e Emprego. Portaria $n^{\circ} 485$, de 11 de novembro de 2005. Aprova a norma regulamentadora $n^{\circ} 32$ (Segurança e saúde no trabalho em estabelecimentos de saúde)[Internet]. Diário Oficial da República Federativa do Brasil, Brasília, DF: 2005[cited 2017 Jun 08]. Available from: http://sbbq.iq.usp.br/arquivos/seguranca/portaria485.pdf

21. Governo do Estado de São Paulo. Secretaria de Estado de Saúde. Manual de Avaliação da qualidade de práticas de controle de infecção hospitalar. São Paulo; 2006.

22. Dean AG, Sullivan KM, Soe MM. OpenEpi: open source epidemiologic statistics for public health, version. 2015.

23. Dancey CP, Reidy J. Estatística sem matemática: para psicologia usando SPSS para Windows. In: Estatística sem matemática: para psicologia usando SPSS para Windows. Artmed; 2006

24. Arenas MD, Payá JS, Barril G, Valdecasas JG, Gorriz, JL, Soriano A, et al. A multicentric survey of the practice of hand hygiene in haemodialysis units: factors affecting compliance. Nephrol Dial Transpl[Internet]. 2005[cited 2017 Jun 08];20(6):1164-71. Available from: https://academic.oup.com/ndt/article-lookup/doi/10.1093/ndt/gfh759

25. Trannin KPP, Campanharo CRV, Lopes MCBT, Okuno MFP, Batista REA. Adesão à higiene das mãos: Intervenção e avaliação. Cogitare Enferm[Internet]. 2016[cited 2017 Jun 05];21(2):1-07. Available from: http://revistas.ufpr.br/cogitare/article/view/44246/28015

26. Souza LM, Ramos MF, Becker ESS, Meirelles LCS, Monteiro SAO. Adherence to the five moments for hand hygiene among intensive care professionals. Rev Gaúcha Enferm[Internet]. 2015[cited 2017 Jun 09];36(4):21-8. Available from: http://www.scielo.br/pdf/ rgenf/v36n4/1983-1447-rgenf-36-04-00021.pdf

27. Primo MGB, Ribeiro LCM, Figueiredo LFS, Sirico SCA, Souza MA. Adesão à prática de higienização das mãos por profissionais de saúde de um Hospital Universitário. Rev Eletr Enferm[Internet]. 2010[cited 2017 Jun 09];12(2):266-71. Available from: https:// www.fen.ufg.br/fen_revista/v12/n2/v12n2a06.htm

28. Ribeiro IP, Rodrigues AM, Silva IC, Santos JD. Riscos ocupacionais da equipe de enfermagem na hemodiálise. Rev Interdis [Internet]. 2016[cited 2017 Jun 08];9(1):143-52. Available from: https://revistainterdisciplinar.uninovafapi.edu.br/index.php/revinter/article/ view/663/pdf_294

29. Rosetti KAG, Tronchin DMR. Compliance of hand hygiene in maintaining the catheter for hemodialysis. Rev Bras Enferm[Internet]. 2015[cited 2017 Jun 07];68(6):1050-55. Available from: http://www.scielo.br/pdf/reben/v68n6/en_0034-7167-reben-68-06-1050.pdf

30. Barreto RASS, Rocha LO, Souza ACS, Tipple AFV, Suzuki K, Bisinoto SA. Higienização das mãos: a adesão entre os profissionais de Enfermagem da sala de recuperação pós-anestésica. Rev Eletr Enferm[Internet]. 2009[cited 2017 Jun 04];11(2):334-40. Available from: https://www.fen.ufg.br/fen_revista/v11/n2/pdf/v11n2a14.pdf

31. Oliveira AC, Paula AO, Gama CS, Oliveira JR, Rodrigues CD. Adesão à higienização das mãos entre técnicos de enfermagem em um hospital universitário. Rev Enferm UERJ[Internet]. 2016[cited 2017 Jun 04];24(2):e9945. Available from: http://www.e-publicacoes. uerj.br/index.php/enfermagemuerj/article/view/9945/19408

32. Brasil. Ministério da Saúde. Agência Nacional de Vigilância Sanitária. RDC nº. 42, de 25 de outubro de 2010: dispõe sobre a obrigatoriedade de disponibilização de preparação alcoólica para fricção antisséptica das mãos, pelos serviços de saúde do País, e dá outras providências. Diário Oficial da União, Brasília, DF: 2010 out 26;157(205) Seção 1:27-8

33. Siqueira SL, Figueiredo AE, Figueiredo CEP, D'Avila OD. Comparison of two hand hygiene techniques in peritoneal dialysis patients. J Bras Nefrol[Internet]. 2012[cited 2017 Jun 07];34(4):355-60. Available from: http://www.scielo.br/pdf/jbn/v34n4/v34n4a08.pdf

34. Prado MF, Hartmann TPS, Teixeira F, Leône A. Acessibilidade da estrutura física hospitalar para a prática da higienização das mãos. Esc Anna Nery Rev Enferm[Internet]. 2013[cited 2017 Jun 08];17(2):220-6. Available from: http://www.scielo.br/pdf/ean/ v17n2/v17n2a03.pdf

35. Bathke J, Cunico PA, Maziero ECS, Cauduro FLF, Sarquis LMM, Cruz EDA. Infrastructure and adherence to hand hygiene: challenges to patient safety. Rev Gaúcha Enferm[Internet]. 2013[cited 2017 Jun 08];34(2):78-85. Available from: http://www.scielo.br/pdf/ rgenf/v34n2/en_v34n2a10.pdf 
36. Oliveira AC, Paula AO. Monitorização da adesão à higienização das mãos: uma revisão de literatura. Acta Paul Enferm[Internet]. 2011[cited 2017 Jun 08];24(3):407-13. Available from: http://www.scielo.br/pdf/ape/v24n3/16.pdf

37. Kukanich KS, Kaur R, Freeman LC, Powell DA. Evaluation of a hand hygiene campaign in outpatient health care clinics. Am J Nurs[Internet]. 2013[cited 2017 May 20];113(3):36-42 Available from: http://dx.doi.org/10.1097/01.NAJ.0000427878.80053.f7

38. Duong MC, McLaws M-L. Dangerous practices in a hemodialysis unit in Vietnam identify from mixed methods. BMC Infect Dis[Internet]. 2017[cited 2017 Jun 26];17:181. Available from: https://www.ncbi.nlm.nih.gov/pmc/articles/PMC5333403/ pdf/12879_2017_Article_2290.pdf

39. Governo do Estado de São Paulo. Secretaria de Estado da Saúde. Centro de Vigilância Epidemiológica. Divisão de infecção hospitalar. Recomendações sobre o uso de luvas em serviços de saúde São Paulo,[Internet]. 2016[cited Jun 2017] Available from: http://www.saude.sp.gov.br/resources/cve-centro-de-vigilancia-epidemiologica/areas-de-vigilancia/infeccao-hospitalar/bmr/doc/ ih16_bmr_uso_luvas.pdf

40. Santos TCR, Roseira CE, Passos IPBD, Figueiredo M. O uso de luvas pela equipe de enfermagem: da proteção ao risco de transmissão. Rev. Enferm UFPE[Internet] 2013[Cited 2017 Jun. 06];7(11):6438-45. Available from: http://www.revista.ufpe.br/revistaenfermagem/ index.php/revista/article/view/4343

41. Melo EM, Pessoa CMP, Lima FET, Barbosa IV, Studart RMB, Souza LP. Cuidados dispensados pela equipe de enfermagem durante o procedimento de punção venosa periférica. Rev. Enferm. UFPE[Internet]. 2015[Cited 2017 May 16];9(3). Available from: http:// www.repositorio.ufc.br/ri/bitstream/riufc/10892/1/2015_art_ivbarbosa.pdf

42. Karkar A, Bouhaha BM, Dammang ML. Infection control in hemodialysis units: a quick access to essential elements. Saudi J Kidney Dis Transpl[Internet]. 2014[cited 2017 Sep 7];25:496-519. Available from: http://www.sjkdt.org/text.asp?2014/25/3/496/132150

43. Ferreira LA, Peixoto CA, Paiva L, Silva QCG, Rezende MP, Barbosa MH. Adherence to standard precautions in a teaching hospital. Rev Bras Enferm[Internet]. 2017[cited 2017 Jun 09];70(1):96-103. Available from: http://www.scielo.br/pdf/reben/v70n1/en_00347167-reben-70-01-0096.pdf

44. Padilha JMFO, Sá SPC, Silvino ZR. Gloves and nursing professionals' adherence to contact precautions: an integrating review. J Nurs UFPE[Internet]. 2017[cited 2017 May 16];11(2). Available from: http://www.revista.ufpe.br/revistaenfermagem/index.php/ revista/article/view/8289/pdf_2567

45. Malaguti-Toffano SE, Santos CB, Canini SRMS, Galvão MTG, Brevidelli MM, Gir E. Adherence to standard precautions by nursing professionals in a university hospital. Acta Paul Enferm[Internet]. 2012[cited 2017 Jun 09];25(3):401-7. Available from: http://www. scielo.br/pdf/ape/v25n3/en_v25n3a13.pdf 